\title{
Time continuum and true long-term ecology: from theory to practice
}

\author{
Valentí Rull * \\ Palynology and Paleoecology Lab, Botanic Institute of Barcelona (IBB-CSIC-ICUB), Barcelona, Spain
}

\section{Edited by:}

Jean Nicolas Haas, University of

Innsbruck, Austria

Reviewed by:

John Birks, University of Bergen, Norway

Simon J. Goring, University of

Wisconsin - Madison, USA

*Correspondence:

Valentí Rull, Palynology and

Paleoecology Lab, Botanic Institute of Barcelona (IBB-CSIC-ICUB),

Passeig del Migdia, s/n (Parc de

Montjuïc), 08038 Barcelona, Spain

e-mail:vrull@ibb.csic.es
The need for long-term studies to understand ecological dynamics is widely recognized but has not been satisfactorily addressed to date. The development of "long-term" (LT) observatories has aimed to improve the situation, but the main handicaps are that we should wait for generations to yield reliable results and that a number of ecological processes occurring at time scales larger than centuries will not be fully resolved. Palaeoecology can provide the needed time scale for true long-term ecology, but it is limited by the ability to merge ecological, and palaeoecological data into continuous time series. This paper suggests a practical way of attaining such goals based on the concept of time continuum. A short review is provided on the main handicaps for palaeoecological records to be incorporated into current ecological datasets and the recent improvements in the field. A global network of past-present-future ecological observatories (PPFEO) centered around lakes with annually-laminated sediments could act as a means of producing truly long-term and continuous ecological records by combining high-resolution palaeoecological techniques with ecological methods commonly used in LT observatories.

Keywords: time continuum, long-term ecology, ecology-palaeoecology synergy, time series, long-term observatories

\section{SPACE AND TIME IN ECOLOGY}

Perhaps one of the main tenets of modern ecology is the notion that relevant ecological patterns and processes should be considered globally to find sound explanations and make accurate predictions about key functional aspects of the biosphere. The study of worldwide biogeochemical cycles and matter/energy balances underwent a spectacular boost during the last decades of the 20th century and has attained a significant amount of data to run models using a global scope (Regnier et al., 2013; Schlesinger and Bernhardt, 2013; Smith et al., 2014). Therefore, in terms of space, ecologists have already attained a solid and likely enduring awareness on the appropriate ecological framework. Time, however, has not been equally appreciated, although some progress has been made. In recent decades, ecologists have realized that many ecological processes should be studied on a long-term basis to infer functional ecosystem features, to calibrate and validate ecological models, and to forecast potential ecological responses to future environmental change (Clutton-Brock and Sheldon, 2010; Magurran et al., 2010). This has led to the creation of global databases (Edwards et al., 2010; Peters, 2010), and the establishment of worldwide networks of ecological observatories that aim to provide "long-term" records of pivotal ecological parameters and processes in the near future (http://www.lternet.edu/). In this context, it is not uncommon to consider decadal or secular ecological time series as "long-term" series. The main handicaps of this approach are that we should wait for generations to yield reliable results and that a number of ecological processes that occur at time scales larger than centuries-e.g., ecological succession, range shifts, migration, extinction, community assembly, biotic responses to global environmental changes, etc.-will not be fully resolved and understood. Present day communities originated and assembled after the Last Glacial Maximum (LGM; between 26,500 and 19,000 years ago) (Lecavalier et al., 2014); therefore, the time frame needed to properly understand their temporal dynamics is larger than one or a few centuries. Palaeoecology can provide the needed time scale for true longterm ecology (Rull and Vegas-Vilarrúbia, 2011), but it is limited by the ability to merge ecological and palaeoecological data into consistent and continuous time series. This paper contends that past-present-future data series of this type are possible and suggests a way of attaining this goal based on the concept of the time continuum.

\section{TIME CONTINUUM}

The conceptual separation between past and present is a human construction. Time is a continuum through which species and communities flow, interact, and evolve. A biosphere of the past and a biosphere of the present do not exist separately; there is a single biosphere where ecological and evolutionary processes have occurred continuously since the origin of life on earth. Therefore, there is no ecology of the past (palaeoecology) and no ecology of the present (modern ecology or neoecology) but rather a single ecology (general ecology) that includes both. Historically, ecology and palaeoecology have been separated for primarily psychological and methodological reasons, not because there are any differences between them per se (Rull, 2010). We hope that the psychological barrier will be overcomed if we are able to find suitable methods to combine ecological and palaeoecological records to produce true long-term records (sensu Rull and Vegas-Vilarrúbia, 2011), rather than insisting on 
the need to merge ecology and palaeoecology from a theoretical framework.

\section{ECOLOGY AND PALAEOECOLOGY}

Some ecological palaeoecologists whose interest is to reconstruct past ecological dynamics rather than solely past environmental changes have addressed the potential usefulness of past records for ecological knowledge (e.g., Davis, 1981; Birks, 1993, 2013a; Jackson, 2001; Flessa and Jackson, 2005; Rull et al., 2013; Seddon et al., 2014). However, these claims have not been fruitful thus far. Some of these palaeoecologists have attempted to enter the ecological arena by publishing papers on palaeoecology in general ecological journals rather than palaeoecological journals (e.g., Birks, 1996; Restrepo et al., 2012; Rull, 2012; Jackson, 2013; Seddon et al., 2014), or by highlighting the usefulness of palaeodata for nature conservation (e.g., Birks, 1993, 1996; Willis et al., 2010; Vegas-Vilarrúbia et al., 2011; Birks, 2013b; Gillson and Marchant, 2014; Seddon et al., 2014). In spite of this, the lack of synergy between ecological and palaeoecological communities persists and is delaying the advancement of ecological knowledge and the potential impact of its applications on important topics, such as nature conservation and the sustainable use of ecological services. A number of ecologists are only interested in present-day ecology or are ignorant of what palaeoecology can tell them. Others are aware of the relevance of palaeoecology but rarely consider past records a useful tool for ecological studies. The more usual reasons for many ecologists to ignore palaeoecological results as potential ecological inputs have been the following (Huntley, 1996, 2012; Rull, 2012): (i) the lack of enough time resolution in palaeoecological reconstructions, (ii) the often incomplete (fragmentary) nature of palaeoecological evidence, (iii) the lack of enough taxonomic resolution, that is, the difficulty of identifying most fossils at the species level, (iv) the difficulty of equating fossil-based measures with present measures, notably abundance and diversity, (v) the lack of taxonomic continuity between past and present communities due to evolution, (vi) the poor development of quantitative methods and the rather qualitative nature of palaeoecological studies in comparison to ecological studies, and (vii) the strong bias of palaeoecologists toward past environmental reconstructions rather than ecological reconstructions. It could be added that the inherently human psychological disconnection between past and present has also been a major handicap for the desired synergies (Rull, 2010). Ecologists should be able to understand and use palaeoecological data but palaeoecologists should also make an extra effort to adapt their data to the requirements of the research field of ecology to promote interaction.

\section{TIME RESOLUTION}

The first point (i) is the responsible for the lack of continuity between ecological and palaeoecological time series. Indeed, palaeoecological surveys of a time resolution comparable to ecological records are very rare. This is a serious handicap that has led to a fundamental disconnection between ecological and palaeoecological databases of global scope (Peng et al., 2011). The time resolution needed for ecological studies varies according to the duration of the lifecycle of the involved organisms.
For example, in the case of forests dominated by trees with life spans of centuries or millennia, decadal studies are clearly insufficient for a sound ecological appraisal. But even in the case of very short life spans, for example in planktonic organisms, there is a seasonal environmental control that makes year round studies (ideally multi-year studies) necessary for a sound understanding of the ecological functioning of these communities (e.g., Köster and Pienitz, 2006; Bunbury and Gajewski, 2008). In palaeoecology, annual resolution is possible in a special type of laminated sediments, referred to as varved sediments, or in cases of very high accumulation rates (Ojala et al., 2012). Laminated sediments are more frequent in continental rather than marine environments, where sedimentation rates are also comparatively lower. Exceptions include certain coastal areas with strong seasonal dynamics that allow the development and preservation of seasonal layers of sediments (Riboulleau et al., 2014). Several detailed studies conducted so far in Europe and North America have demonstrated the high ecological potential of these special types of sediments but this potential has not been fully exploited yet (Hughes and Ammann, 2009). In temperate regions, dendrochronology can provide powerful highresolution tools to study forest dynamics (Foster et al., 2014; Galván et al., 2014). Other palaeoecological archives that could be useful for ecological purposes are the growth rings of corals (Bramanti et al., 2014), speleothems (Feurdean et al., in press), or ice cores (Alley, 2011). Studies of annual resolution are feasible and meaningful for both ecology and palaeoecology; therefore, annual resolution seems to be an excellent link to produce continuous, homogeneous, and coherent long-term ecological records (Figure 1).

\section{RECORD INCOMPLETENESS AND TAXONOMIC RESOLUTION}

Record incompleteness (point ii) may refer to the lack of continuity in the sedimentary records themselves or to the biased representation of organisms in the fossil record due to differential preservation, or both. Sedimentary continuity tends to be higher in permanent water bodies than in terrestrial and temporarily flooded environments, due to either erosion, the lack of deposition, or both. Additionally, continuity is usually higher in recent (Quaternary) sediments than in older sediments, which have been submitted to more tectonic and erosional processes. The preferred locations for palaeoecologists seeking continuous sedimentary records are lakes that originated after the LGM. Differential preservation favors the persistence of organisms with hard elements able to endure post-depositional diageneses, whereas others that might be equally significant from an ecological point of view are lost. Fortunately, palaeoecological methods are continuously advancing, and we now have a wide range of new possibilities beyond the classical paleontology. Indeed, organisms without hard structures may be recorded in the sediments by their characteristic chemical imprints (biomarkers), and also by their genetic material (DNA, RNA) that can be analyzed at a molecular level and identified to species resolution (e.g., Boere et al., 2009; Coolen et al., 2013) (point iii). Molecular palaeoecology is now in full expansion (Anderson-Carpenter et al., 2011; Hofreiter et al., 2012), and will likely lead to significant improvements toward more complete palaeocommunity reconstructions. 




FIGURE 1 | Timescales of ecological and palaeoecological studies showing the shared temporal window, ranging from seasons to decades. The higher resolution (HR) of combined ecological-

palaeoecological time series is attained using seasonal records, whereas the lower resolution (LR) occurs in decadal records. In palaeoecology, seasonal resolution is more difficult to attain than annual resolution, which is more feasible and seems a suitable framework for continuous long-term ecological records.

\section{ABUNDANCE AND DIVERSITY}

Biases in the fossil record due to differential preservation also determine inconsistencies between the abundance of a given fossil and the abundance of its parent organism in the original living community (point iv). In some cases, these inconsistencies are magnified by other processes such as differential production and transport, as occurs in the case of pollen. As a consequence, diversity measures, such as richness and equitability, are commonly distorted in the fossil assemblage compared to the living community. Several strategies have attempted to quantitatively calibrate fossil and living abundances using modern analogs (Jackson and Williams, 2004; Jackson, 2012). In these studies, the basic assumption (based on the principle of uniformitarianism) is that modern fossil assemblages, once sedimented, have been submitted to the same processes as fossil assemblages, except for diagenesis. Therefore, we can calibrate the abundance of the components of a modern assemblage with parameters from their sources, such as relative abundance of the living organism involved, its cover (in the case of vegetation), the distance to its source, and other quantitative relationships (Gaillard et al., 2008; Zheng et al., 2014), to generate models and transfer functions that can be applied to fossil assemblages to estimate the past values for these parameters. The diversity of fossil assemblages cannot give direct and accurate measures of the diversity of the original living community. The better cases are those of fossils representing complete organisms, such as diatoms or foraminifers; the worst case is again represented by vegetation reconstruction using pollen analysis. One possibility to address this problem could be the combined use of pollen and macrofossils, which are more local in origin and less dependent on production and transport factors (Birks and Birks, 2000). However, as macrofossils are random parts of the whole organism, diversity estimation is always problematic. Some studies have shown that pollen diversity and vegetation diversity do not coincide (Goring et al., 2013), while others show that their trends can be consistent, and it may be possible to derive community diversity changes in time from fossil diversity tendencies (van der Knaap, 2009). Diversity estimation using transfer functions has been rarely attempted and might be potentially useful.
Research in this field is presently very active (Goring et al., 2013; Keen et al., 2014).

\section{EVOLUTION AND COMMUNITY TURNOVER}

Points $\mathrm{v}$ and vi refer to taxonomic turnover of communities due to speciation and extinction, which makes past and present communities incomparable, or at least discontinuous in time. Extant communities were assembled and developed during the Quaternary, where many new species emerged and others became extinct (Davis, 1981; Huntley and Birks, 1983; Graham et al., 1996; Rull, 2011). These communities, however, have remained relatively constant during the Late Glacial and the Holocene, where no significant speciation and extinction events have been documented, and spatial reorganization in response to environmental changes has been the rule (Willis and Bhagwat, 2009). Exceptions are communities that have been significantly modified as a result of the megafaunal extinctions occurred during the Late Pleistocene, which affected not only animal but also plant communities (Gill et al., 2009). Contrastingly, one single plant extinction has been documented so far for the whole Quaternary, which occurred during the last deglacial phase (Jackson and Weng, 1999). Therefore, the Late Glacial and the Holocene can provide us a truly long record of extant community dynamics and internal and external drivers involved, which can be especially useful as past analogs to infer potential ecological responses to eventual future environmental changes (Williams and Jackson, 2007; Williams et al., 2007).

\section{QUANTITATIVE DEVELOPMENTS}

In the past, palaeoecological and palaeoenvironmental reconstructions were mostly qualitative or semi-quantitative, but this has notably changed during recent decades. At present, palaeoecological studies are based on quantitative multivariate datasets that are analyzed with a variety of statistical techniques including the latest developments in numerical analysis (Birks et al., 2010, 2012; Birks, 2013c). Additionally, several regional and global databases exist that are available to researchers interested in developing meta-analysis on particular subjects and selected time 
intervals (Fyfe et al., 2009; Peng et al., 2011; Brewer et al., 2012; Grimm et al., 2013). It could be said that the idea of Palaeoecology as a qualitative discipline is a myth that is no longer tenable, but it is equally true that there is still room for improvement in the use of numerical methods and datasets for palaeoecological research.

\section{ECOLOGICAL PALAEOECOLOGY}

Point vii is still a challenge for ecology and palaeoecology integration, but there are signs of change that are encouraging. For example, the concept of ecological palaeoecology, although it may seem redundant, has emerged from the need of differentiating palaeoecologists interested in ecological dynamics from those whose aim is to reconstruct past environments, mostly addressing climate. Palaeoclimatology is now experiencing a significant development, as it has proven to be useful to calibrate and validate global climatic models based on general circulation and energy balance, as well as to reconstruct past atmospheric and oceanic circulation, thus suggesting previously unknown causal mechanisms for climate change. These developments are commonly used in forecasts of future global change (Stocker et al., 2013). Ecological palaeoecologists have also conducted some steps in the potential application of palaeoecological results to ecological knowledge in general, especially in reference to nature conservation in the face of future events (Willis et al., 2010; VegasVilarrúbia et al., 2011; Gillson and Marchant, 2014), but there is still much room for improvement.

\section{CONTINUOUS PAST-PRESENT-FUTURE TIME SERIES IN PRACTICE}

To overcome the drawbacks discussed above, we need practical proposals. Presently, the theoretical basis for fruitful ecologicalpalaeoecological synergies seems robust, and a large number of priority hypotheses and questions that need to be addressed have already been identified (Seddon et al., 2014). Now, we need a feasible strategy to put them into practice. We should be able to combine present-day ecology with palaeoecology in a way that can be satisfactory for the practitioners of both disciplines who are willing to share the common objective of understanding the ecological functioning of the biosphere-the common goal of ecology and palaeoecology (Rull, 2010). Thus, far, palaeoecologists have attempted to attract the attention of ecologists by highlighting the suitability of palaeo-data for ecology, but this has been unsuccessful. Therefore, new ideas are necessary. A more pragmatic strategy is to launch collaborative projects of long-term ecological research that include past (palaeoecology), present (modern ecology), and future (ecological monitoring) evidence aimed at combining all these data in a single time series of the same temporal and taxonomic resolution. An initiative of this type is the PalEON Project, which aim is "to reconstruct forest composition, fire regime and climate in forests across the northwestern US and Alaska over the past 2000 years and then use this to derive and validate terrestrial ecosystem models." (http://www3.nd.edu/ paleolab/paleonproject/).

To develop a global network of continuous long-term ecological records of annual resolution, we do not need to create any special infrastructure, as the already existing network of "longterm" ecological observatories (LTER and similar) may represent a good starting point. In some cases, we could benefit from the already existing LTER sites to develop palaeoecological and palaeolimnological studies in lakes located near these sites. Examples are some alpine lakes of the Colorado Front Range (USA), where high-resolution palaeolimnological studies on nitrogen deposition during the last centuries has been used to forecast potential future biotic responses to anthropogenic pressure, as part of the study of the Niwot Ridge LTER site (Wolfe et al., 2000). In other cases, we could propose the emplacement of new ecological monitoring stations inside catchments with suitable palaeoecological archives, thus transforming these eventual observatories into truly long-term stations. According to the six points analyzed above, the optimal locations for these past-present-future ecological observatories (PPFEO) would be catchments with lakes containing continuous and annually laminated sedimentary records that include the Late Glacial and the Holocene. The advantage of lake sediments is that they contain fossils from the aquatic biota and also from terrestrial ecosystems present in the catchment thus facilitating integral palaeolimnological and palaeoecological reconstructions. Ideally, this procedure should be developed synchronously at different representative locations worldwide to obtain a global scope. In this way, we might be capable of producing continuous records of annual resolution since the LGM. This time scale appears sufficient to find well-documented explanations of ecological change at the ecosystem level, as well as to optimize functional and predictive ecological models.

An example of continuous and homogeneous past-present records of annual resolution is provided by Northern Hemisphere temperature reconstructions of the last millennium (Figure 2). Similar long-term ecological records would be possible for subjects as varied as population dynamics, community assembly, ecological succession, biodiversity shifts, migration patterns and range shifts, biotic responses to environmental changes, changes in forest cover, land use patterns, fire incidence, nitrogen deposition, carbon sequestration, or lake acidification, among many others. Such long-term annual data series would provide huge and coherent datasets with optimal statistical reliability to be analyzed with numerical methods and unravel trends, cycles, and other processes impossible to be captured at decadal to centennial time scales. In addition, it would be possible to check whether the present-day ecological state is consistent with historical trends or, on the contrary, it is anomalous, as it occurs for example with modern temperature trends as compared to the last millennium records (Figure 2).

\section{CONCLUDING REMARKS}

According to the points discussed above, palaeoecology is able to achieve temporal and taxonomic resolutions compatible with modern ecology observations using continuous long-term (millennial) quantitative records of extant community change and its drivers. It appears that the continuity between palaeoecological and ecological time series is possible, provided we are capable of improving several aspects of palaeoecological data and their presentation. Improvements are still needed in the seven areas discussed above, particularly on points iii (taxonomic resolution), and iv (abundance and diversity measures), but recent advances in molecular genetics are very promising and have been 


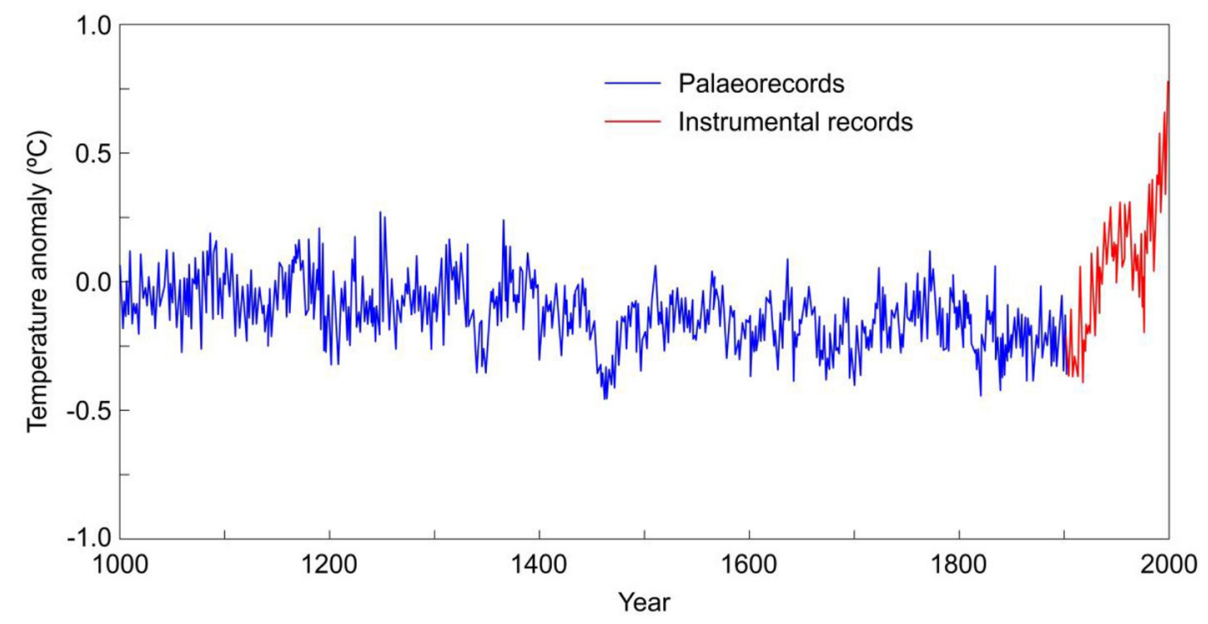

FIGURE 2 | Northern Hemisphere temperature reconstructions of the last millennium. Palaeorecords are based on tree rings and ice cores, present-day records are from instrumental measures.
Temperature anomalies are calculated using the average annual temperature of the period 1902-1980. Redrawn from Mann et al. (1999). successful in other ecological areas (Cavender-Bares et al., 2009, 2012; Marske et al., 2013). Despite the remaining limitations, the launch of collaborative long-term projects of the type suggested in this paper is already possible and may be the best strategy to identify the methodological and psychological aspects that require further attention for true ecological-palaeoecological synergies.

\section{REFERENCES}

Alley, R. B. (2011). Reliability of ice-core science: historical insights. J. Glaciol. 56, 1095-1103. doi: 10.3189/002214311796406130

Anderson-Carpenter, L., McLachlan, J. S., Jackson, S. T., Kuch, M., Lumibao, C. Y., and Poinar, H. N. (2011). Ancient DNA from lake sediments: bridging the gap between paleoecology and genetics. BMC Evol. Biol. 11:30. doi: 10.1186/14712148-11-30

Birks, H. H., and Birks, H. J. B. (2000). Future uses of pollen analysis must include plant macrofossils. J. Biogeogr. 27, 31-35. doi: 10.1046/j.13652699.2000.00375.x

Birks, H. J. B. (1993). Quaternary paleoecology and vegetation science-current contributions and possible future developments. Rev. Palaeobot. Palynol. 79, 153-177. doi: 10.1016/0034-6667(93)90045-V

Birks, H. J. B. (1996). Contributions of Quaternary palaeoecology to nature conservation. J. Veg. Sci. 7, 89-98. doi: 10.2307/3236420

Birks, H. J. B. (2013a). "Paleoecology," in Encyclopedia of Ecology: Reference Module in Earth Systems and Environmental Sciences, ed S. A. Elias (Amsterdam: Elsevier). doi: 10.1016/B978-0-12-409548-9.00884-8

Birks, H. J. B. (2013b). Ecological palaeoecology and conservation biology: controversies, challenges, and compromises. Int. J. Biodiv. Sci. Ecosyst. Serv. Manage. 8, 292-304. doi: 10.1080/21513732.2012.701667

Birks, H. J. B. (2013c). "Numerical analysis methods," in Encyclopedia of Quaternary Science eds S. A. Elias and C. J. Mock (Amsterdam: Elsevier), 821-830.

Birks, H. J. B., Heiri, O., Seppä, H., and Bjune, A. (2010). Strengths and weaknesses of quantitative climate reconstructions based on Late-Quaternary biological proxies. Open Ecol. J. 3, 68-110. doi: 10.2174/1874213001003020068

Birks, H. J. B., Lotter, A. F., Juggins, S., and Smol, J. P. (eds.). (2012). Tracking Environmental Change Using Lake Sediments. Data Handling and Numerical Techniques. Dordrecht: Springer. doi: 10.1007/978-94-007-2745-8

Boere, A. C., Abbas, B., Rijpstra, W. I. C., Versteegh, G. J. M., Volkman, J. K., Damste, J. S. S., et al. (2009). Late-Holocene succession of dinoflagellates in an Antarctic fjord using a multi-proxy approach: paleoenvironmental genomics, lipid biomarkers and palynomorphs. Geobiology 7, 265-281. doi: $10.1111 / j .1472-4669.2009 .00202 . x$
Bramanti, L., Vielmini, I., Rossi, S., Tsounis, G., Ianelli, M., Cattaneo-Vietti, R., et al. (2014). Demographic parameters ot two populations of red coral (Corallium rubrum L. 1758) in the North Western Mediterranean. Mar. Biol. 161, 1015-1026. doi: 10.1007/s00227-013-2383-5

Brewer, S., Jackson, S. T., and Williams, J. W. (2012). Paleoecoinformatics: applying geohistorical data to ecological questions. Trends Ecol. Evol. 27, 104-112. doi: 10.1016/j.tree.2011.09.009

Bunbury, J., and Gajewski, K. (2008). Does a one point sample adequately characterize the lake environment for paleoenvironmental calibration studies? J. Paleolimnol. 39, 511-531. doi: 10.1007/s10933-0079127-9

Cavender-Bares, J., Ackerly, D. D., and Kozak, K. H. (2012). Integrating ecology and phylogenetics: the footprint of history in modern-day communities. Ecology 93 , S1-S3. doi: 10.1890/12-0092.1

Cavender-Bares, J., Kozach, K. H., Fine, P. V. A., and Kembel, S. W. (2009). The merging of community ecology and phylogenetic biology. Ecol. Lett. 12, 693-715. doi: 10.1111/j.1461-0248.2009.01314.x

Clutton-Brock, T., and Sheldon, B. C. (2010). Individuals and populations: the role of long-term, individual-based studies of animals in ecology and evolutionary biology. Trends Ecol. Evol. 25, 562-573. doi: 10.1016/j.tree.2010. 08.002

Coolen, M. J., Orsi, W. D., Balkema, C., Quince, C., Harris, K., Sylva, S. P., et al. (2013). Evolution of the plankton paleome in the Black Sea from the Deglacial to Anthropocene. Proc. Natl. Acad. Sci. U.S.A. 110, 8609-8614. doi: 10.1073/pnas.1219283110

Davis, M. B. (1981). "Quaternary history and the stability of forest communities," in Forest Succession, Concepts and Applications, eds D. C. West, D. B. Shugart, and D. B. Botkin (New York, NY: Springer), 152-153.

Edwards, M., Beaugrand, G., Hays, G. C., Koslow, J. A., and Richardson, A. J. (2010). Multi-decadal oceanic ecological datasets and their application in marine policy and management. Trends Ecol. Evol. 25, 602-610. doi: 10.1016/j.tree.2010.07.007

Feurdean, A., Perşiou, A., Tanţău, I., Stevens, T., Magyari, E. K., Onac, B. P., et al. (in press). Climate variability and associated vegetation response throughout central and eastern europe (CEE) between 60 and 8 ka. Quat. Sci. Rev. doi: 10.1016/j.quascirev.2014.06.003

Flessa, K. V., and Jackson, S. T. (2005). Forging a common agenda for ecology and paleoecology. Bioscience 55, 1030-1031. doi: 10.1641/00063568(2005)055[1030:FACAFE]2.0.CO;2

Foster, J. R., D'Amatto, A. W., and Bradford, J. B. (2014). Looking for age-related growth decline in natural forests: unexpected biomass patterns from tree rings and simulated mortality. Oecologia 175, 363-374. doi: 10.1007/s00442-0142881-2 
Fyfe, R. M., de Beaulieu, J.-L., Binney, H., Bradshaw, R. H. W., Brewer, S., Flao, A. L., et al. (2009). The European Pollen Database: past efforts and current activities. Veg. Hist. Archaeobot. 18, 417-424. doi: 10.1007/s00334-009-0215-9

Gaillard, M.-J., Sugita, S., Bunting, M. J., Middleton, R., Broström, A., Caseldine, C., et al. (2008). The use of modelling and simulation approach in reconstructing past landscapes from fossil pollen data: a review and results from the POLLANDCAL network. Veg. Hist. Archaeobot. 17, 419-443. doi: 10.1007/s00334-008-0169-3

Galván, J. D., Camarero, J. J., and Gutiérrez, E. (2014). Seeing the trees for the forest: drivers of individual growth responses to climate in Pinus uncinata mountains forests. J. Ecol. 102, 1244-1257. doi: 10.1111/1365-2745.12268

Gill, J. L., Williams, J. W., Jackson, S. T., Lininger, K. B., and Robinson, G. S. (2009). Pleistocene megafaunal collapse, novel plant communities, and enhanced fire regimes in North America. Science 326, 1100-1103. doi: 10.1126/science. 1179504

Gillson, L., and Marchant, R. (2014). From myopia to clarity: sharpening the focus of ecosystem management through the lens of palaeoecology. Trends Ecol. Evol. 29, 317-325. doi: 10.1016/j.tree.2014.03.010

Goring, S., Lacourse, T., Pellatt, M. G., and Mathewes, R. W. (2013). Pollen assemblage richness does not reflect regional plant species richness: a cautionary tale. J. Ecol. 191, 1137-1145. doi: 10.1111/1365-2745.12135

Graham, R. W., Lundelius, E. L., Graham, M. A., Schroeder, E. K., Toomey, R. S., Anderson, E., et al. (1996). Spatial response of mammals to late Quaternary environmental fluctuations. Science 272, 1601-1606. doi: $10.1126 /$ science. 272.5268 .1601

Grimm, E. C., Bradshaw, R. H. W., Brewer, S., Flantua, S., Giesecke, T., Lézine, A. M., et al. (2013). "Databases and their application," in Encyclopaedia of Quaternary Science, ed S. A. Elias (Amsterdam: Elsevier), 831-838. doi: 10.1016/B978-0-444-53643-3.00174-6

Hofreiter, M., Collins, M., and Stewart, J. R. (2012). Ancient biomolecules in quaternary palaeoecology. Quat. Sci. Rev. 33, 1-13. doi: 10.1016/j.quascirev.2011.11.018

Hughes, M. K., and Ammann, C. M. (2009). The future of the past-an earth system framework for high resolution paleoclimatology. Clim. Change 3-4, 247-259. doi: 10.1007/s10584-009-9588-0

Huntley, B. (1996). Quaternary palaeoecology and ecology. Quat. Sci. Rev. 15, 591-606. doi: 10.1016/0277-3791(96)00015-7

Huntley, B. (2012). Reconstructing palaeoclimates from biological proxies: some often overlooked sources of uncertainty. Quat. Sci. Rev. 31, 1-16. doi: 10.1016/j.quascirev.2011.11.006

Huntley, B., and Birks, H. J. B. (1983). An Atlas of Past and Present Pollen Maps for Europe, 0-13000 Years Ago. Cambridge: Cambridge University Press.

Jackson, S. T. (2001). Integrating ecological dynamics across timescales, realtime, Q-time and deep time. Palaios 16, 1-2. doi: 10.1669/08831351(2001)0162.0.CO;2

Jackson, S. T. (2012). Representation of flora and vegetation in Quaternary fossil assemblages: known and unknown knowns and unknowns. Quat. Sci. Rev. 49, 1-15. doi: 10.1016/j.quascirev.2012.05.020

Jackson, S. T. (2013). Natural, potential and actual vegetation in North America. J. Veg. Sci. 24, 772-776. doi: 10.1111/jvs.12004

Jackson, S. T., and Weng, C. (1999). Late Quaternary extinction of a tree species in eastern North America. Proc. Natl. Acad. Sci. U.S.A. 96, 13847-13852. doi: 10.1073/pnas.96.24.13847

Jackson, S. T., and Williams, J. W. (2004). Modern analogs in Quaternary paleoecology: here today, gone yesterday, gone tomorrow? Annu. Rev. Earth Planet. Sci. 32, 495-537. doi: 10.1146/annurev.earth.32.101802.120435

Keen, H. F., Gosling, W. D., Hanke, F., Miller, C. S., Montoya, E., Valencia, B. G., et al. (2014). A statistical sub-sampling tool for extracting vegetation community and diversity information from pollen assemblage data. Palaeogeogr. Palaeoclimatol. Palaeoecol. 408, 48-59. doi: 10.1016/j.palaeo.2014.05.001

Köster, D., and Pienitz, R. (2006). Seasonal diatom variability and paleolimnological inferences-a case study. J. Paleolimnol. 35, 395-416. doi: 10.1007/s10933005-1334-7

Lecavalier, B. S., Milne, G. A., Simpson, M. J. R., Wake, L., Huybrechts, P., Tarasov, L., et al. (2014). A model for Greenland ice sheet deglaciation constrained by observations of relative sea level and ice extent. Quat. Sci. Rev. 102, 54-84. doi: 10.1016/j.quascirev.2014.07.018

Magurran, A. E., Baillie, S. R., Buckland, S. T., Dick, J. M., Elston, D. A., Scott, M., et al. (2010). Long-term datasets in biodiversity research and monitoring: assessing change in ecological communities through time. Trends Ecol. Evol. 25, 574-582. doi: 10.1016/j.tree.2010.06.016

Mann, M. E., Bradley, R. S., and Hughes, M. K. (1999). Northern Hemisphere temperatures during the last millennium: inferences, uncertainties and limitations. Geophys. Res. Lett. 26, 759-762. doi: 10.1029/1999GL900070

Marske, K. A., Rahbeck, C., and Nogués-Bravo, D. (2013). Phylogeography: spanning the ecological-evolutionary gap. Ecography 36, 1169-1181. doi: 10.1111/j.1600-0587.2013.00244.x

Ojala, A. E. K., Francus, P., Zolitschka, B., Besonen, M., and Lamoureux, S. F. (2012). Characteristics of sedimentary varve chronologies-a review. Quat. Sci. Rev. 43, 45-60. doi: 10.1016/j.quascirev.2012.04.006

Peng, C. H., Guiot, J., Wu, H., Jiang, H., and Luo, Y. (2011). Integrating model data in ecology and palaeoecology: advances towards a model-data fusion approach. Ecol. Lett. 14, 522-536. doi: 10.1111/j.1461-0248.2011.01603.x

Peters, D. P. C. (2010). Accessible ecology: synthesis of the long, deep, and broad. Trends Ecol. Evol. 25, 592-601. doi: 10.1016/j.tree.2010.07.005

Regnier, P., Friedlingstein, P., Ciais, P., Mackenzie, F. T., Gruber, N., Janssens, I. A., et al. (2013). Anthropogenic perturbation of the carbon fluxes from land to ocean. Nat. Geosci. 6, 597-607. doi: 10.1038/ngeo1830

Restrepo, A., Colinvaux, P., Bush, M., Correa-Metrio, A., Conroy, J., Gardener, M. R., et al. (2012). Impacts of climate variability and human colonization on the vegetation of the Galápagos Islands. Ecology 93, 1853-1866. doi: 10.1890/111545.1

Riboulleau, A., Bout-Roumazeilles, V., and Tribovillard, N. (2014). Controls on detrital sedimentation in the Cariaco Basin during the last climatic cycle: insights from clay minerals. Quat. Sci. Rev. 94, 62-73. doi: 10.1016/j.quascirev.2014.04.023

Rull, V. (2010). Ecology and palaeoecology: two approaches, one objective. Open Ecol. J. 3, 1-5. doi: 10.2174/1874213001003020001

Rull, V. (2011). Neotropical biodiversity: timing and potential drivers. Trends Ecol. Evol. 26, 508-513. doi: 10.1016/j.tree.2011.05.011

Rull, V. (2012). Community ecology: diversity and dynamics over time. Comm. Ecol. 13, 102-116. doi: 10.1556/ComEc.13.2012.1.13

Rull, V., Montoya, E., Nogué, S., Vegas-Vilarrúbia, T., and Safont, E. (2013). Ecological paleoecology in the neotropical Gran Sabana region: long-term records of vegetation dynamics as a basis for ecological hypothesis testing. Persp. Plant Ecol. Evol. Syst. 15, 338-359. doi: 10.1016/j.ppees.2013.07.004

Rull, V., and Vegas-Vilarrúbia, T. (2011). What is long term in ecology? Trends Ecol. Evol. 26, 3-4. doi: 10.1016/j.tree.2010.10.002

Schlesinger, W., and Bernhardt, E. (2013). Biogeochemistry. An Analysis of Global Change. Amsterdam: Elsevier-Academic Press.

Seddon, A. W. R., Mackay, A. W., Baker, A. G., Birks, H. J. B., Breman, E., Buck, C. E., et al. (2014). Looking forward through the past: identification of 50 priority questions in palaeoecology. J. Ecol. 102, 256-267. doi: 10.1111/1365-2745. 12195

Smith, B., Warlind, D., Arneth, A., Hickler, T., Leadley, P., Stilberg, J., et al. (2014). Implications of incorporating $\mathrm{N}$ cycling and $\mathrm{N}$ limitations on primary production in an individual-based dynamic vegetation model. Biogeosci. 11, 2027-2054. doi: 10.5194/bg-11-2027-2014

Stocker, T. F., Qin, D., Plattner, G.-K., Tinor, M. M. B., Allen, S. K., Boschung, J., et al. (2013). Climate Change 2013. The Physical Science Basis. Cambridge: Cambridge University Press.

van der Knaap, W. O. (2009). Estimating pollen diversity from pollen accumulation rates: a method to assess taxonomic richness in the landscape. Holocene 19, 159-163. doi: 10.1177/0959683608098962

Vegas-Vilarrúbia, T., Rull, V., Montoya, E., and Safont, E. (2011). Quaternary palaeoecology and nature conservation with an emphasis on global warming and fire, with examples from the Neotropics. Quat. Sci. Rev. 30, 2361-2388. doi: 10.1016/j.quascirev.2011.05.006

Williams, J. W., and Jackson, S. T. (2007). Novel climates, no-analogue communities, and ecological surprises. Front Ecol. Environ. 5,475-482. doi: $10.1890 / 070037$

Williams, J. W., Jackson, S. T., and Kutzbach, J. E. (2007). Projected distributions of novel and disappearing climates by 2100 AD. Proc. Natl. Acad. Sci. U.S.A. 104, 5738-5742. doi: 10.1073/pnas.0606292104

Willis, K. J., Bailey, R. M., Bhagwat, S., and Birks, H. J. B. (2010). Biodiversity baselines, thresholds and resilience: testing predictions and assumptions using palaeoecological data. Trends Ecol. Evol. 25, 583-591. doi: 10.1016/j.tree.2010.07.006 
Willis, K. J., and Bhagwat, S. (2009). Biodiversity and climate change. Science 326, 806-807. doi: 10.1126/science.1178838

Wolfe, A. P., Baron, J. S., and Cornett, R. J. (2000). Anthropogenic nitrogen deposition induces rapid ecological changes in alpine lakes of the Colorado Front Range (USA). J. Paleolimnol. 25, 1-7. doi: 10.1023/A:1008129509322

Zheng, Z., Wei, J., Huang, K., Xu, Q., Lu, H., Tarasov, P., et al. (2014). East Asian pollen database: modern pollen distribution and its quantitative relationship with vegetation and climate. J. Biogeogr. 41, 1819-1832. doi: 10.1111/jbi.12361

Conflict of Interest Statement: The author declares that the research was conducted in the absence of any commercial or financial relationships that could be construed as a potential conflict of interest.
Received: 08 September 2014; accepted: 31 October 2014; published online: 17 November 2014.

Citation: Rull V (2014) Time continuum and true long-term ecology: from theory to practice. Front. Ecol. Evol. 2:75. doi: 10.3389/fevo.2014.00075

This article was submitted to Paleoecology, a section of the journal Frontiers in Ecology and Evolution.

Copyright $\odot 2014$ Rull. This is an open-access article distributed under the terms of the Creative Commons Attribution License (CC BY). The use, distribution or reproduction in other forums is permitted, provided the original author(s) or licensor are credited and that the original publication in this journal is cited, in accordance with accepted academic practice. No use, distribution or reproduction is permitted which does not comply with these terms. 